\title{
A comparative analytical study of clinical outcome of oligohydramnios at or beyond 34 weeks of gestation
}

\author{
Sunita TH*, Shraddha Neminath Kurkure, Rathnamala M. Desai, Vidya Kamath
}

Department of Obstetrics and Gynaecology, SDM Medical College, Dharwad, Karnataka, India

Received: 26 February 2016

Revised: 23 April 2016

Accepted: 07 May 2016

*Correspondence:

Dr. Sunita TH,

E-mail: srposdm@yahoo.com

Copyright: () the author(s), publisher and licensee Medip Academy. This is an open-access article distributed under the terms of the Creative Commons Attribution Non-Commercial License, which permits unrestricted non-commercial use, distribution, and reproduction in any medium, provided the original work is properly cited.

\begin{abstract}
Background: Amniotic fluid volume measurement forms an integral part of the antenatal fetal monitoring. It is widely used as an indicator of fetal wellbeing during third trimester. The four quadrant method of calculating AFI as described by Phelan et al is accepted by most of the authors. Oligohydramnios in pregnancy without a renal abnormality or genitourinary obstruction represents "chronic in utero stress". Perinatal morbidity and mortality are significantly increased in oligohydramnios. So oligohydramnios was taken up for further study in order to devise methods and means to know the cause, diagnose and manage it in a better way. The aim of the study was to study the maternal and perinatal outcome in oligohydramnios at or beyond 34 weeks of gestation.

Methods: This comparative analytical study was done in pregnant women with AFI $<5 \mathrm{~cm}$ diagnosed at/after 34 weeks of gestation attending antenatal clinic at department of OBG, Shri Dharmasthala Manjunatheshwara College of Medical Sciences and Hospital, Dharwad from November 2012 to October 2013. Clinical outcome was compared with pregnant women having normal AFI $(6-24 \mathrm{~cm})$ at/after 34 weeks of gestation. For all women AFI and NST were done. UAD was done in women with oligohydramnios. Patients with abnormal NST and/or Doppler studies at the time of diagnosis or any time during fetal surveillance were considered for termination of pregnancy. In pregnant women with normal AFI, NST was done once in two weeks or as necessity demanded. Various clinical outcomes were measured using appropriate statistical measurements.

Results: In presence of oligohydramnios, the occurrence of non-reactive NST, meconium stained liquor, development of fetal distress, LSCS rate; low Apgar score, low birth weight babies, NICU admissions and early neonatal deaths were high.

Conclusions: Determination of AFI is a valuable parameter, which can be used as an adjunct to other fetal surveillance methods. It helps to identify neonates at risk of poor perinatal outcome.
\end{abstract}

Keywords: Amniotic fluid index, Oligohydramnios, Caesarean section, Non-stress test, Fetal distress, Perinatal mortality

\section{INTRODUCTION}

Amniotic fluid volume measurement forms an integral part of the antenatal fetal monitoring, which is a part of routine obstetric scan. It is widely used as an indicator of fetal wellbeing during third trimester. Although subjective and semi quantitative methods of estimating amniotic fluid volume ultrasonographically are in use, best method remains controversial. However, the technique of four quadrant method of calculating amniotic fluid index as described by Phelan et al is accepted by most of the authors. ${ }^{1}$

Reported incidence varies between $0.5 \%$ to $>5 \%$ depending on definition of oligohydramnios and population studied. Phelan who described amniotic fluid index (AFI), defined oligohydramnios as AFI less than 5 $\mathrm{cm}^{2}$ Oligohydramnios in a pregnancy without a renal 
abnormality or genitourinary obstruction represents "chronic in utero stress". Perinatal morbidity and mortality are significantly increased in oligohydramnios. ${ }^{3}$

In our study we wanted to study clinical outcome in oligohydramnios and compare them with pregnant women with normal AFI at or beyond 34 weeks of gestation. So oligohydramnios was taken up for further study in order to devise methods and means to know the cause, diagnose and manage it in a better way.

The aim of the study was to study the maternal and perinatal outcome in oligohydramnios at or beyond 34 weeks of gestation.

\section{METHODS}

This comparative analytical study was done in pregnant women with AFI $<5$ centimetres diagnosed at or after 34 weeks of gestation attending antenatal clinic at Department of Obstetrics and Gynaecology, Shri Dharmasthala Manjunatheshwara College of Medical Sciences and Hospital, Dharwad from November 2012 to October 2013. Clinical outcome in pregnant women with AFI $<5$ centimetres was compared with pregnant women having normal AFI $(6-24 \mathrm{~cm})$ at or after 34 weeks of gestation.

\section{Inclusion criteria}

- Gestational age between 34 weeks- 42 weeks

- Singleton gestation with cephalic presentation

- $\mathrm{AFI}<5 \mathrm{~cm}$

- Intact membranes

\section{Exclusion criteria}

- Associated fetal malformations

- Gestational age less than 34 weeks and more than 42 weeks

- $\quad$ Ruptured membranes

- Multiple gestation

- Intrauterine death

- Fetal malpresentation

- Polyhydramnios

For all the selected cases with good dating, thorough history was taken and complete examination was done. Clinical evidence of oligohydramnios was looked for. The previous obstetric records and ultrasound reports were reviewed. For all women baseline investigations like blood group and $\mathrm{Rh}$ typing, hemoglobin, urine examination (albumin, sugar and microscopy), HIV, HBsAg and VDRL were done. For all women, ultrasound examination was done and amniotic fluid was calculated by four quadrant amniotic fluid volume measurement technique. For each case, a control was taken with similar gravidity, parity and gestational age. NST was done for all women. NST result was considered reactive if 2 accelerations of $>15$ beats/min (bpm) from baseline and lasting >15 seconds were present during a 20-minute period. NST was considered abnormal if baseline variability was less than $5 \mathrm{bpm}$ with late decelerations or repetitive variable decelerations at least three in 20 minutes even if mild or decelerations lasting 1 minute or longer.

Umbilical artery Doppler was performed at the middle of the umbilical cord in pregnant women with oligohydramnios. This was considered abnormal if S/D ratio was above $95^{\text {th }}$ percentile for corresponding gestational age or if diastolic flow was either absent or reversed.

If NST was reactive close fetal surveillance was done by biweekly NST till 37 weeks of gestation in oligohydramnios patients. Patients with abnormal NST and/or Doppler studies at the time of diagnosis or any time during fetal surveillance were considered for termination of pregnancy. In pregnant women with normal AFI, NST was done once in two weeks or as necessity demanded.

\section{Outcomes}

\section{Maternal outcome}

1. Gestational age at the time of delivery

2. Whether induction of labour was required?

3. Route of delivery : vaginal/caesarean

4. Colour of the amniotic fluid : clear/meconium stained (thin/thick)

5. NST : reactive/non-reactive

6. Umbilical artery Doppler : normal/abnormal

\section{Perinatal outcome}

1. Birth weight of the baby

2. Apgar scores at 1 minute and 5 minutes

3. Whether the baby required NICU admission?

4. Whether the baby had aspirated meconium?

5. Whether the baby had respiratory distress syndrome?

6. Early neonatal deaths

Appropriate statistical measurement like rates, ratios, percentages, proportions, mean $\pm \mathrm{SD}$ or number were used. Also ' $\mathrm{t}$ ' test and 'chi square' test were used. P-value < 0.05 was considered statistically significant.

\section{RESULTS}

Our comparative analytical study was performed in 50 pregnant women with the AFI of $<5 \mathrm{~cm}$ and gestational 
age of $>34$ weeks. These women were compared with 50 pregnant women with normal AFI. Study and control groups were similar with variables i.e. maternal age, gravidity, parity, gestational age and antenatal complications.

The mean age for study group was 24.36 years and that of control group was 23.86 years. There was no significant difference in the mean age between two groups statistically. The age distribution is shown in Table 1.

Table 1: Age distribution in study and control groups.

\begin{tabular}{|lllll|}
\hline $\begin{array}{l}\text { Age } \\
\text { groups } \\
\text { (years) }\end{array}$ & $\begin{array}{l}\text { Study } \\
\text { group }\end{array}$ & $\%$ & $\begin{array}{l}\text { Control } \\
\text { group }\end{array}$ & $\%$ \\
\hline $18-20$ & 6 & 12.00 & 8 & 16.00 \\
\hline $21-25$ & 28 & 56.00 & 30 & 60.00 \\
\hline $26-30$ & 13 & 26.00 & 10 & 20.00 \\
\hline $31-35$ & 3 & 6.00 & 2 & 4.00 \\
\hline Total & 50 & 100.00 & 50 & 100.00 \\
\hline Mean age & 24.36 & & 23.86 & \\
\hline SD & 3.29 & & 3.13 & \\
\hline p-value & 0.4379 & & & \\
\hline
\end{tabular}

There was no significant difference in the gravidity between two groups statistically

Table 2: Gravidity distribution in study and control groups.

\begin{tabular}{|lllll|}
\hline Gravidity & $\begin{array}{c}\text { Study } \\
\text { group }\end{array}$ & $\%$ & $\begin{array}{l}\text { Control } \\
\text { group }\end{array}$ & $\%$ \\
\hline Gravida 1 & 29 & 58.00 & 29 & 58.00 \\
\hline Gravida 2 & 14 & 28.00 & 13 & 26.00 \\
\hline Gravida 3 & 3 & 6.00 & 4 & 8.00 \\
\hline Gravida 4 & 3 & 6.00 & 4 & 8.00 \\
\hline Gravida 5 & 1 & 2.00 & 0 & 0.00 \\
\hline Total & 50 & 100.00 & 50 & 100.00 \\
\hline Chi-square $=0.1801$ & p-value $=0.9812$ \\
\hline
\end{tabular}

Table 3: Parity distribution in study and control groups.

\begin{tabular}{|lllll|}
\hline Parity & $\begin{array}{l}\text { Study } \\
\text { group }\end{array}$ & $\%$ & $\begin{array}{l}\text { Control } \\
\text { group }\end{array}$ & $\%$ \\
\hline Nullipara & 36 & 72.00 & 34 & 68.00 \\
\hline Para 1 & 12 & 24.00 & 13 & 26.00 \\
\hline Para 2 & 1 & 2.00 & 2 & 4.00 \\
\hline Para 3 & 1 & 2.00 & 1 & 2.00 \\
\hline Para 4 & 0 & 0.00 & 0 & 0.00 \\
\hline Total & 50 & 100.00 & 50 & 100.00 \\
\hline Chi-square & $=0.0827$ & p-value $=0.9571$ & \\
\hline
\end{tabular}

The mean gestational age was 38.06 weeks for study group and 38.24 weeks for control group. There was no significant difference in the distribution of gestational age between two groups statistically as shown in Table 4.

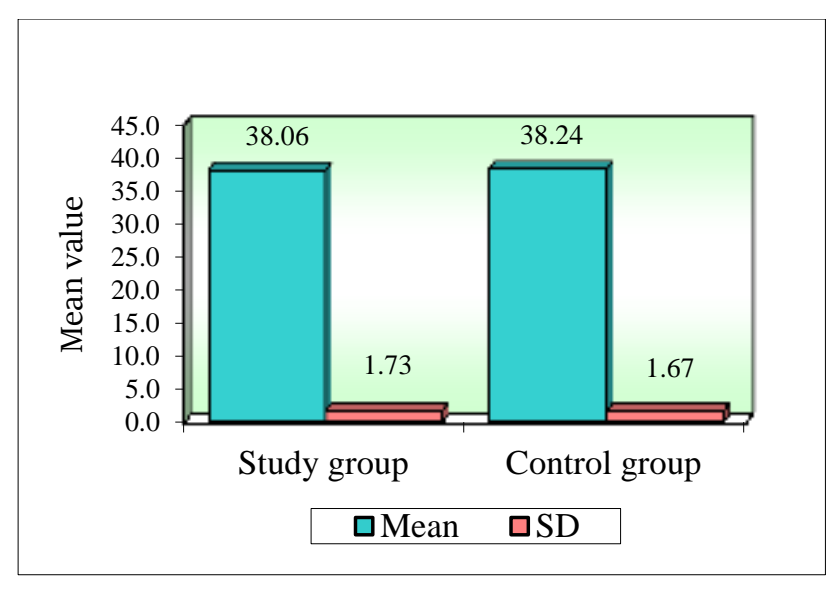

Figure 1: Comparison of mean gestational age in weeks between study and control groups.

Various antenatal complications that were noted in our study include pre-eclampsia and post-dated pregnancy. These complications occurred in $36 \%$ of women in the study group and $36 \%$ of women in the control group as shown in Table 5.

Table 4: Comparison of gestational age between study and control groups.

\begin{tabular}{|lllll|}
\hline $\begin{array}{l}\text { Gestational } \\
\text { age } \\
\text { (weeks) }\end{array}$ & $\begin{array}{l}\text { Study } \\
\text { group }\end{array}$ & $\%$ & $\begin{array}{l}\text { Control } \\
\text { group }\end{array}$ & $\%$ \\
\hline 34 & 1 & 2.0 & 1 & 2.0 \\
\hline 35 & 3 & 6.0 & 2 & 4.0 \\
\hline 36 & 5 & 10.0 & 4 & 8.0 \\
\hline 37 & 9 & 18.0 & 9 & 18.0 \\
\hline 38 & 12 & 24.0 & 12 & 24.0 \\
\hline 39 & 10 & 20.0 & 11 & 22.0 \\
\hline 40 & 5 & 10.0 & 6 & 12.0 \\
\hline 41 & 5 & 10.0 & 5 & 10.0 \\
\hline Total & 50 & 100.00 & 50 & 100.00 \\
\hline Mean & 38.06 & & 38.24 & \\
\hline SD & 1.73 & & 1.67 & \\
\hline p-value & 0.5982 & & & \\
\hline
\end{tabular}

Table 5: Antenatal complications in study and control groups.

\begin{tabular}{|lllll|}
\hline $\begin{array}{l}\text { Antenatal } \\
\text { complications }\end{array}$ & $\begin{array}{l}\text { Study } \\
\text { group }\end{array}$ & $\%$ & $\begin{array}{l}\text { Control } \\
\text { group }\end{array}$ & $\%$ \\
\hline $\begin{array}{l}\text { Mild pre- } \\
\text { eclampsia }\end{array}$ & 5 & 10.00 & 4 & 8.00 \\
\hline $\begin{array}{l}\text { Severe pre- } \\
\text { eclampsia }\end{array}$ & 3 & 6.00 & 3 & 6.00 \\
\hline $\begin{array}{l}\text { Post-dated } \\
\text { pregnancy }\end{array}$ & 9 & 18.00 & 10 & 20.00 \\
\hline $\begin{array}{l}\text { Post-dated } \\
\text { pregnancy with } \\
\text { pre-eclampsia }\end{array}$ & 1 & 2.00 & 1 & 2.00 \\
\hline Total & 18 & 36.00 & 18 & 36.00 \\
\hline
\end{tabular}


The mean AFI in study group was $4.03 \mathrm{~cm}$ and in control group was $10.84 \mathrm{~cm}$ as shown in Table 6.

Table 6: Distribution of AFI in study and control groups.

\begin{tabular}{|llll|l|}
\hline $\begin{array}{l}\text { AFI } \\
(\mathrm{cm})\end{array}$ & $\begin{array}{l}\text { Study } \\
\text { group }\end{array}$ & $\%$ & $\begin{array}{l}\text { Control } \\
\text { group }\end{array}$ & $\%$ \\
\hline $2-3$ & 9 & 18.00 & - & - \\
\hline $3.1-4$ & 23 & 46.00 & - & - \\
\hline $4.1-5$ & 18 & 36.00 & - & - \\
\hline $5.1-8$ & - & - & 1 & 2.00 \\
\hline $\begin{array}{l}8.1- \\
11\end{array}$ & - & - & 33 & 66.00 \\
\hline $\begin{array}{l}11.1- \\
14\end{array}$ & - & - & 12 & 24.00 \\
\hline $\begin{array}{l}14.1- \\
17\end{array}$ & - & - & 4 & 8.00 \\
\hline Total & 50 & 100.00 & 50 & 100.00 \\
\hline Mean & 4.03 & & 10.84 & \\
\hline
\end{tabular}

The outcome parameters analysed include NST, nature of amniotic fluid, induction of labour rate, mode of delivery, occurrence of instrumental vaginal delivery and LSCS for fetal distress, Apgar score at 1 minute and 5 minutes, birth weight of the baby, NICU admission and early neonatal deaths.

The NST was non-reactive in 24 (48\%) women in study group and $8(16 \%)$ in control group. The difference in the NST pattern between the two groups was statistically significant as shown in Table 7.

Table 7: NST pattern in study and control groups.

\begin{tabular}{|c|c|c|c|c|}
\hline NST & $\begin{array}{l}\text { Study } \\
\text { group }\end{array}$ & $\%$ & $\begin{array}{l}\text { Control } \\
\text { group }\end{array}$ & $\%$ \\
\hline Reactive & 26 & 52.0 & 42 & 84.0 \\
\hline Non-reactive & 24 & 48.0 & 8 & 16.0 \\
\hline Total & 50 & 100.0 & 50 & 100.0 \\
\hline
\end{tabular}

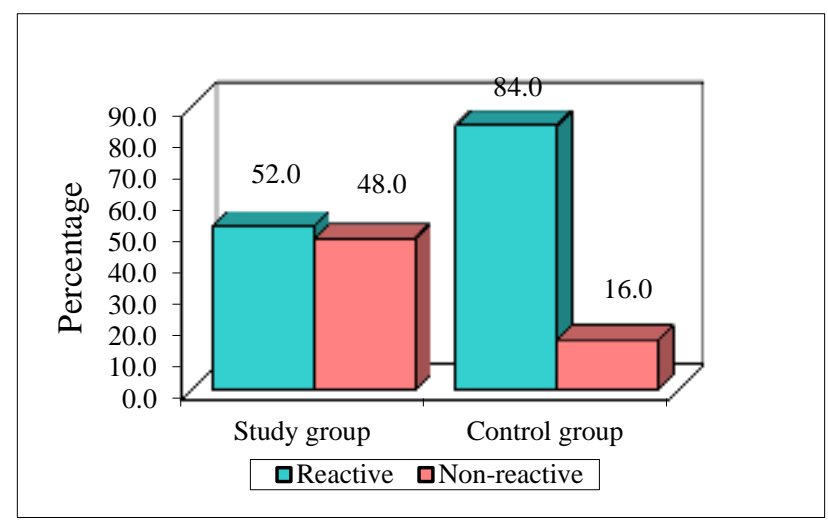

Figure 2: NST pattern in study and control groups.
The amniotic fluid was thick meconium stained in 16 (32\%) and thin meconium stained amniotic fluid in 6 (12\%) women of study group. In control group, $3(6 \%)$ women had thick meconium stained amniotic fluid and 3 (6\%) women had thin meconium stained amniotic fluid. The difference in occurrence of meconium stained amniotic fluid between two groups was statistically significant (p-value $<0.05$ ) as shown in Table 8.

Table 8: Nature of amniotic fluid in study and control groups.

\begin{tabular}{|lllll|}
\hline $\begin{array}{l}\text { Nature of } \\
\text { amniotic fluid }\end{array}$ & $\begin{array}{l}\text { Study } \\
\text { group }\end{array}$ & $\%$ & $\begin{array}{l}\text { Control } \\
\text { group }\end{array}$ & $\%$ \\
\hline Clear & 28 & 56.0 & 44 & 88.0 \\
\hline Thin meconium & 6 & 12.0 & 3 & 6.0 \\
\hline Thick meconium & 16 & 32.0 & 3 & 6.0 \\
\hline Total & 50 & 100.0 & 50 & 100.0 \\
\hline Chi-square $=13.450$ & p-value $=0.001 *$ \\
\hline
\end{tabular}

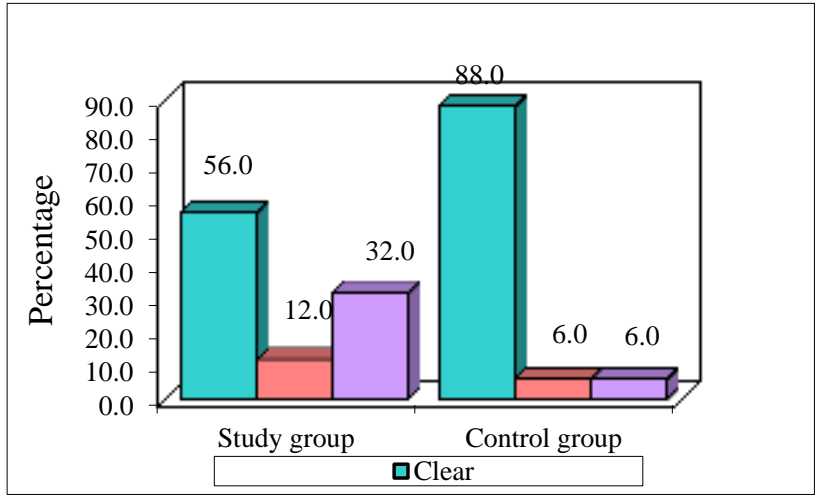

Figure 3: Nature of amniotic fluid in study and control groups.

Labour was induced in $22(44 \%)$ women in the study group and $11(22 \%)$ women in the control group. The difference between two groups was statistically significant (p-value $<0.05$ ) as shown in Table 9.

Table 9: Induced vs Spontaneous labour in study and control groups.

\begin{tabular}{|lllll|}
\hline Labour & $\begin{array}{l}\text { Study } \\
\text { group }\end{array}$ & Control & $\%$ \\
\hline Induced & 22 & 44.00 & 11 & 22.00 \\
\hline Spontaneous & 6 & 12.00 & 35 & 70.00 \\
\hline Chi-square $=21.046 ;$ & p-value $=0.0001 * ; * \mathrm{p}<0.05$ \\
\hline
\end{tabular}

Caesarean delivery (LSCS) was done in $30(60 \%)$ women and instrumental vaginal delivery in $9(18 \%)$ women in the study group. In control group, 7 (14\%) women delivered by caesarean delivery and $6(12 \%)$ women by instrumental vaginal delivery. The difference between two groups was statistically significant (p-value $<0.05)$ as shown in Table 14. 


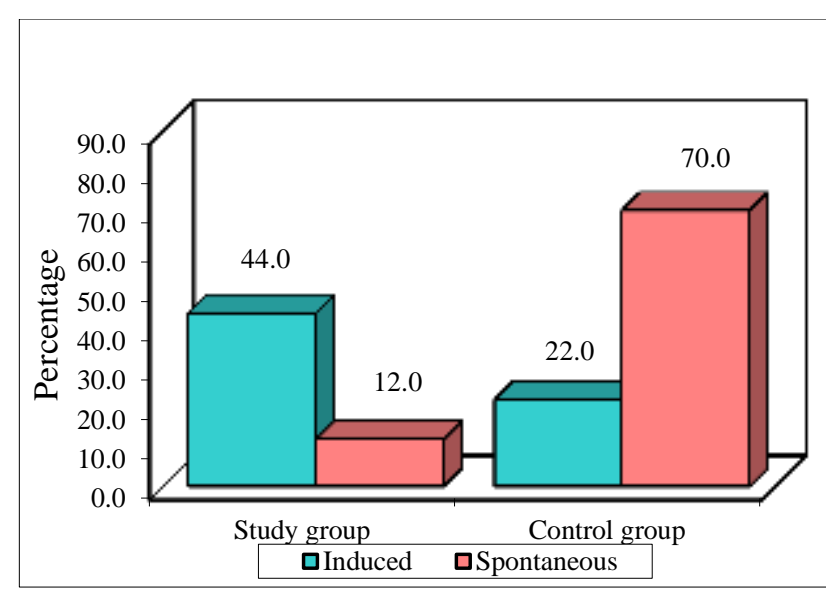

Figure 4: Induced vs Spontaneous labour in study and control groups.

Table 10: Mode of delivery in study and control groups.

\begin{tabular}{|lllll|}
\hline $\begin{array}{l}\text { Mode of } \\
\text { delivery }\end{array}$ & $\begin{array}{l}\text { Study } \\
\text { group }\end{array}$ & $\%$ & $\begin{array}{l}\text { Control } \\
\text { group }\end{array}$ & $\%$ \\
\hline Vaginal & 11 & 22.00 & 37 & 74.00 \\
\hline $\begin{array}{l}\text { Instrumental } \\
\text { vaginal }\end{array}$ & 9 & 18.00 & 6 & 12.00 \\
\hline LSCS & 30 & 60.00 & 7 & 14.00 \\
\hline Total & 50 & 100 & 50 & 100 \\
\hline Chi-square $=28.9821 ; \mathrm{p}$-value $=0.0001 * ;{ }^{*} \mathrm{p}<0.05$ \\
\hline
\end{tabular}

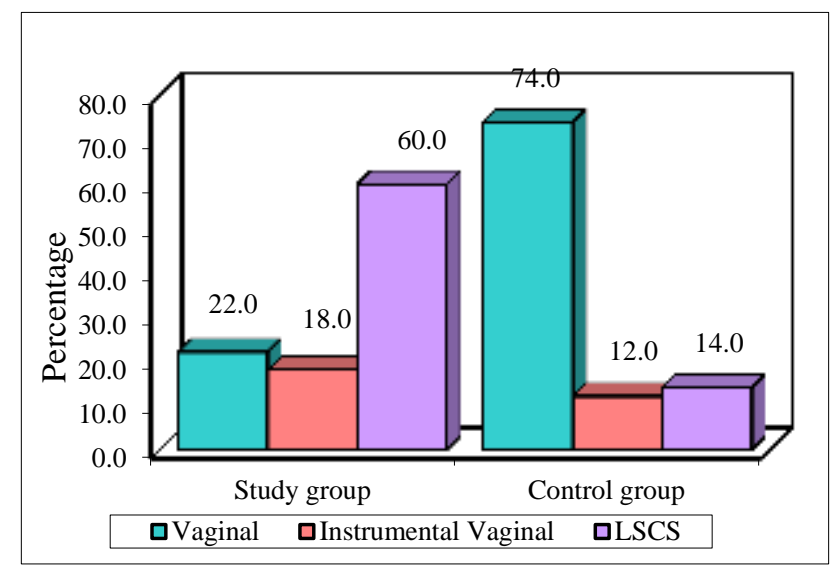

Figure 5: Mode of delivery in study and control groups.

In study group, 38 (76\%) women developed fetal distress (includes women with non-reactive NST on admission or at any time during labour). Of them, 30 (60\%) women delivered by caesarean delivery and $8(16 \%)$ delivered by instrumental vaginal delivery. In control group, 12 (24\%) women developed fetal distress. Of them, 7 (14\%) women delivered by caesarean section and $5(10 \%)$ delivered by instrumental vaginal delivery. Our study shows that women with oligohydramnios developing fetal distress and undergoing caesarean section was quite high though p-value was not significant as shown in Table 11.
Table 11: Interventions for fetal distress in study and control groups.

\begin{tabular}{|lllll|}
\hline Interventions & $\begin{array}{l}\text { Fetal } \\
\text { distress } \\
\text { in study } \\
\text { group }\end{array}$ & $\%$ & $\begin{array}{l}\text { Fetal } \\
\text { distress in } \\
\text { control } \\
\text { group }\end{array}$ & $\%$ \\
\hline LSCS & 30 & 60 & 7 & 14 \\
\hline $\begin{array}{l}\text { Instrumental } \\
\text { vaginal delivery }\end{array}$ & 8 & 16 & 5 & 10 \\
\hline Total & 38 & 76 & 12 & 24 \\
\hline Chi-square $=2.0114$ p-value $=0.1562$ & \\
\hline
\end{tabular}

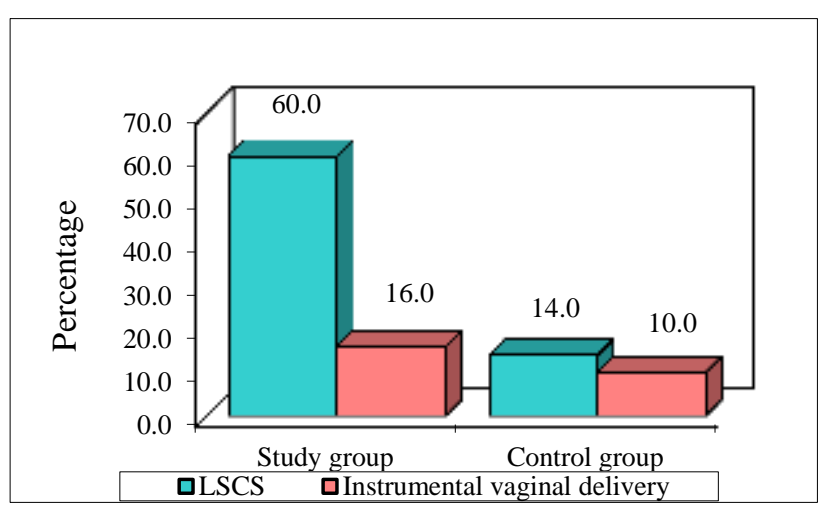

Figure 6: Interventions for fetal distress in study and control groups.

The determination of AFI $\leq 5 \mathrm{~cm}$ as a screening test in predicting fetal distress requiring LSCS has $81 \%$ sensitivity, $68 \%$ specificity, $60 \%$ positive predictive value and $86 \%$ negative predictive value. A better sensitivity and negative predictive value makes it a good screening test.

In 26 women with reactive NST in study group, 4 had spontaneous vaginal delivery (there were 3 instrumental vaginal deliveries) and 22 were induced. Of 22 induced women, 14 delivered vaginally (there were 6 instrumental vaginal deliveries) and 08 underwent LSCS as shown in Table 12.

Table 12: Different outcomes in women with reactive NST in both groups.

\begin{tabular}{|lll|}
\hline Different outcomes & $\begin{array}{l}\text { Study } \\
\text { group }\end{array}$ & $\begin{array}{l}\text { Control } \\
\text { group }\end{array}$ \\
\hline $\begin{array}{l}\text { Spontaneous vaginal delivery } \\
\text { (including instrumental) }\end{array}$ & 04 & 31 \\
\hline $\begin{array}{l}\text { Induced and delivered vaginally } \\
\text { (including instrumental) }\end{array}$ & 14 & 08 \\
\hline Induced and underwent LSCS & 08 & 03 \\
\hline
\end{tabular}

In 24 women with non-reactive NST in study group, 2 had spontaneous vaginal delivery and 22 underwent LSCS as shown in Table 13. 
Table 13: Different outcomes in women with nonreactive NST in both groups.

\begin{tabular}{|l|c|c|}
\hline $\begin{array}{l}\text { Different outcomes } \\
\text { Spontaneous vaginal }\end{array}$ & Study group & Control group \\
\hline $\begin{array}{l}\text { delivery (including } \\
\text { instrumental) }\end{array}$ & 02 & 04 \\
\hline LSCS & 22 & 04 \\
\hline
\end{tabular}

Table 14: Apgar score <7 in study and control groups.

\begin{tabular}{|llcl|l|}
\hline $\begin{array}{l}\text { Apgar } \\
\text { score }\end{array}$ & $\begin{array}{l}\text { Study } \\
\text { group }\end{array}$ & $\%$ & $\begin{array}{l}\text { Control } \\
\text { group }\end{array}$ & $\%$ \\
\hline 1 minute & 27 & 54.00 & 10 & 20.00 \\
\hline 5 minutes & 5 & 10.00 & 1 & 2.00 \\
\hline Chi-square $=$ & $=0.2918$ & p-value $=0.5909$ & \\
\hline
\end{tabular}

In study group, Apgar score was $<7$ at 1 minute in 27 $(54 \%)$ neonates and at 5 minutes in $5(10 \%)$ neonates. But in control group, Apgar score was $<7$ at 1 minute in $10(20 \%)$ neonates and at 5 minutes in $1(2 \%)$ neonate even though it was not significant statistically as shown in Table 14. The mean Apgar score in study group was 6.4 at 1 minute and 7.68 at 5 minutes. The mean Apgar score in control group was 7.06 at 1 minute and 8.34 at 5 minutes.

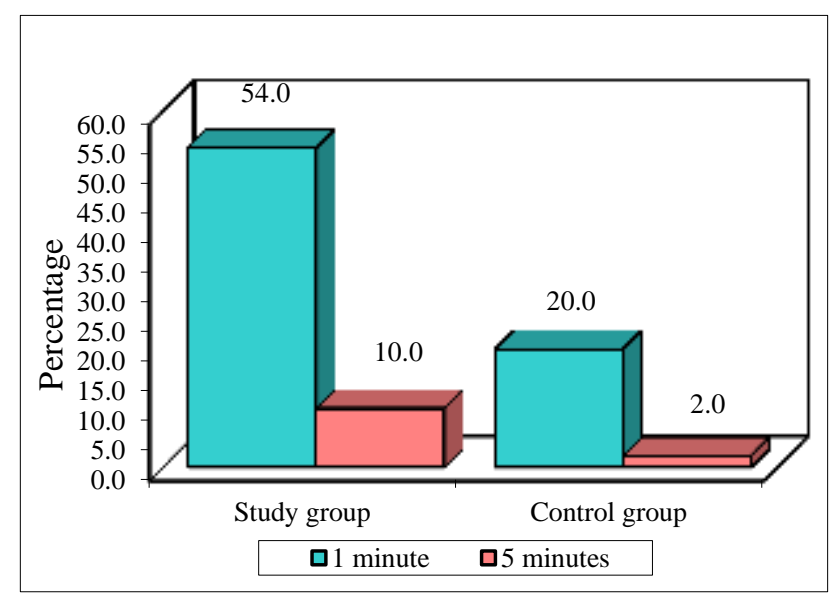

Figure 7: Apgar score < 7 in study and control groups.

The birth of the babies with $<2.5 \mathrm{~kg}$ birth weight was seen in $29(58 \%)$ women in study group and $10(20 \%)$ women in control group as shown in Table 15. The mean birth weight of babies in study group was $2.34 \mathrm{~kg}$ and $2.86 \mathrm{~kg}$ in control group.

In study group, $30(60 \%)$ neonates were admitted to NICU for various reasons like birth asphyxia, meconium aspiration, and low birth weight. Only 12 (24\%) neonates were admitted to NICU, in control group as shown in Table 16. The difference was significant statistically between two groups.
Table 15: Birth weights in study and control groups.

\begin{tabular}{|lllll|}
\hline $\begin{array}{l}\text { Birth weights } \\
\text { (in kg) }\end{array}$ & $\begin{array}{l}\text { Study } \\
\text { group }\end{array}$ & $\%$ & $\begin{array}{l}\text { Control } \\
\text { group }\end{array}$ & $\%$ \\
\hline$\leq 1.5$ & 8 & 16.00 & 0 & 0.00 \\
\hline $1.6-2.0$ & 8 & 16.00 & 1 & 2.00 \\
\hline $2.1-2.5$ & 13 & 26.00 & 9 & 18.00 \\
\hline $2.6-3.0$ & 14 & 28.00 & 24 & 48.00 \\
\hline $3.1-3.5$ & 7 & 14.00 & 15 & 30.00 \\
\hline$>3.5$ & 0 & 0.00 & 1 & 2.00 \\
\hline \multicolumn{5}{l}{ Chi-square $=20.1166$} \\
\hline
\end{tabular}

Table 16: NICU admission of neonates in study and control groups.

\begin{tabular}{|lllll|}
\hline $\begin{array}{l}\text { NICU } \\
\text { admission }\end{array}$ & $\begin{array}{l}\text { Study } \\
\text { group }\end{array}$ & $\%$ & $\begin{array}{l}\text { Control } \\
\text { group }\end{array}$ & $\%$ \\
\hline Yes & 30 & 60.0 & 12 & 24.0 \\
\hline No & 20 & 40.0 & 38 & 76.0 \\
\hline Total & 50 & 100.0 & 50 & 100.0 \\
\hline Chi-square & $=13.3002 ; \mathrm{p}$-value $=0.0001 * ;{ }^{*} \mathrm{p}<0.05$ \\
\hline
\end{tabular}

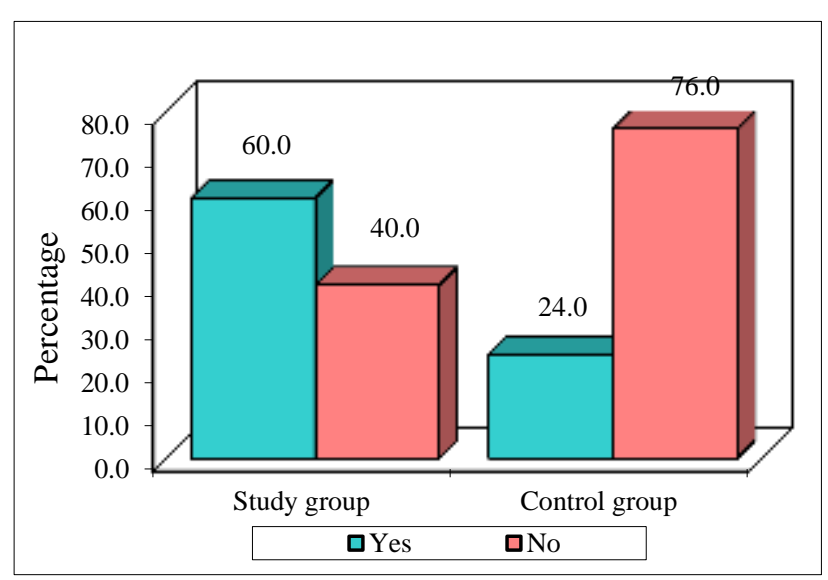

Figure 8: NICU admission of neonates in study and control groups.

There were $3(6 \%)$ early neonatal deaths in study group and $1(2 \%)$ early neonatal death in control group as shown in Table 17.

Table 17: Early neonatal deaths in study and control groups.

\begin{tabular}{|lllll|}
\hline $\begin{array}{l}\text { Neonatal } \\
\text { deaths }\end{array}$ & $\begin{array}{l}\text { Study } \\
\text { group }\end{array}$ & $\%$ & $\begin{array}{l}\text { Control } \\
\text { group }\end{array}$ & $\%$ \\
\hline Yes & 3 & 6.0 & 1 & 2.0 \\
\hline No & 47 & 94.0 & 49 & 98.0 \\
\hline Total & 50 & 100.0 & 50 & 100.0 \\
\hline \multicolumn{2}{l}{ Chi-square } & $=0.2604$ & p-value & $=0.6103$ \\
\hline
\end{tabular}

Umbilical artery Doppler was done for all women with oligohydramnios. It was normal in 28 (56\%) women. Increased resistance flow, absent diastolic flow and reversal of diastolic flow in umbilical artery Doppler was 
seen in $5(10 \%), 15(30 \%)$ and $2(4 \%)$ women respectively as shown in Table 18 .

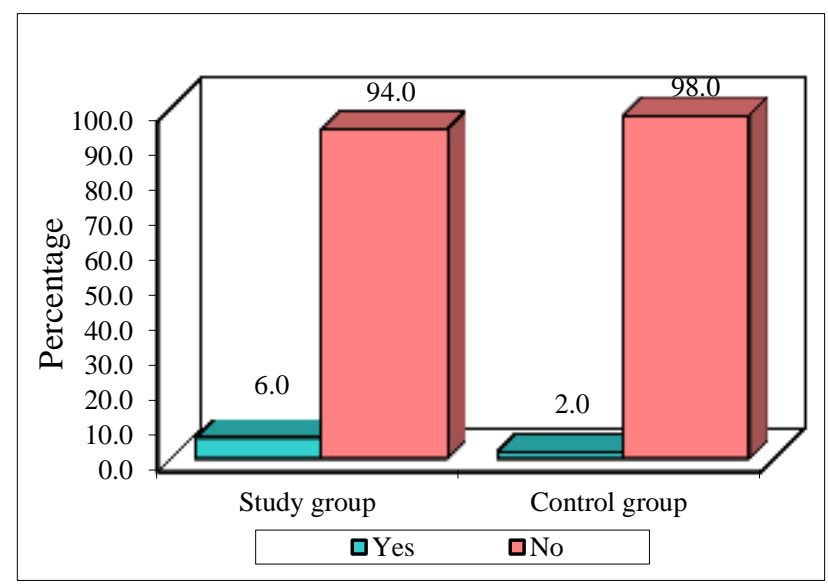

Figure 9: Early neonatal deaths in study and control groups.

Table 18: UAD of pregnant women with AFI $<5 \mathrm{~cm}$ (study group).

\begin{tabular}{|lll|}
\hline UAD & No of cases & $\%$ of cases \\
\hline Normal & 28 & 56.00 \\
\hline Increased resistance flow & 5 & 10.00 \\
\hline Absent diastolic flow & 15 & 30.00 \\
\hline Reversal of diastolic flow & 2 & 4.00 \\
\hline
\end{tabular}

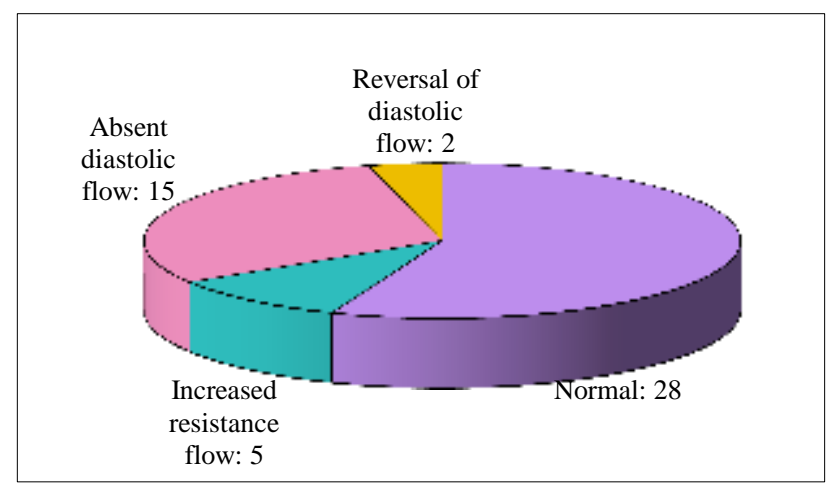

Figure 10: UAD of pregnant women with AFI $=/<5$ cm (study group, $n=50$ ).

\section{DISCUSSION}

Various variables and outcome results of our study are comparable to the results of similar studies done both in India and abroad.

Mean maternal age (in years) of study group in present study was 24.36 compared to $27.04,22.88$ and 23.9 in study by Bhagat $\mathrm{M}$ and Chawla I, Bangal VB et al and Casey BM et al respectively. ${ }^{4}$ In a study by Jandial C et al, $48 \%$ women belonged to 21-25 years of age group. ${ }^{5}$ Mean maternal age (in years) in a study by Melamed $\mathrm{N}$ et al, was 28.2 in active delivery group and 28.1 in expectant management group. ${ }^{6}$

In our study group primigravida accounted for $58 \%$ compared to $60 \%$ in the study by Jandial C et al.

In our study group $72 \%$ women were nullipara compared to $68 \%, 40 \%$ and $60.3 \%$ in study by Bhagat $\mathrm{M}$ and Chawla I, Casey BM et al and Melamed $\mathrm{N}$ et al respectively. In our control group $68 \%$ women were nullipara compared to $58.9 \%, 37 \%$ and $57.4 \%$ in study by Bhagat $\mathrm{M}$ and Chawla I, Casey BM et al and Melamed N et al respectively. In present study mean gestational age at delivery was $38.06 \pm 1.73$ weeks compared to $38 \pm 2$ weeks in study by Casey BM et al. In study by Bhagat M and Chawla I, $56 \%$ of women were $<37$ weeks of gestational age at delivery. In study by Melamed $\mathrm{N}$ et al, gestational age at delivery was $36.7 \pm 1.1$ weeks in active delivery group and $38.9 \pm 1.7$ weeks in expectant management group.

Hypertensive disorders which cause chronic placental insufficiency lead to oligohydramnios. In our study group $16 \%$ women had only pre-eclampsia compared to $16 \%$, $12 \%$ and $4.6 \%$ in study by Bangal VB et al, Casey BM et al, Melamed $\mathrm{N}$ et al respectively. ${ }^{7}$ Post-dated pregnancy only was seen in $18 \%$ of women in study group in present study compared to $16 \%$ in study by Bangal VB et al. Amniotic fluid volume is known to be reduced with advancing gestational age after 40 weeks.

NST was non-reactive in $48 \%$ women of our study group compared to $32 \%$ and $38 \%$ in a study by Bhagat $\mathrm{M}$ and Chawla I and Jandial C et al respectively. Occurrence of meconium stained amniotic fluid was high in women with AFI $\leq 5 \mathrm{~cm}$. Amniotic fluid was meconium stained in $44 \%$ of our study group compared to $16 \%, 48 \%, 6 \%$ and $6.7 \%$ in study by Bhagat $\mathrm{M}$ and Chawla I, Jandial C et al, Casey $\mathrm{BM}$ et al and Melamed $\mathrm{N}$ et al respectively.

In present study group, $44 \%$ of women were induced (induction of labour) compared to $72 \%, 58 \%$ and $42 \%$ in study by Bhagat $\mathrm{M}$ and Chawla I, Jandial $\mathrm{C}$ et al and Casey BM et al respectively. Caesarean delivery (LSCS) for fetal distress was done in $60 \%$ women of our study group compared to $57.1 \%, 42 \%$ and $5 \%$ in study by Bhagat $\mathrm{M}$ and Chawla I, Jandial $\mathrm{C}$ et al and Casey BM et al. respectively. In study by Melamed $\mathrm{N}$ et al, 59\% women in active delivery group and $16.7 \%$ in expectant management group underwent caesarean delivery for fetal distress.

Apgar score was $<7$ at 1 minute in $54 \%$ neonates in present study group compared to $36 \%$ and $10 \%$ in study by Bhagat $M$ and Chawla $I$ and Bangal VB et al respectively. Apgar score was $<7$ at 5 minutes in $10 \%$ neonates in present study group compared to $4 \%, 16 \%$ and $12 \%$ in study by Bhagat $\mathrm{M}$ and Chawla I, Bangal VB et al and Jandial $\mathrm{C}$ et al respectively. In present study group $58 \%$ neonates birth weight was less than $2.5 \mathrm{~kg}$, 
compared to $56 \%, 58 \%$ and $35 \%$ in study by Bhagat $\mathrm{M}$ and Chawla I, Jandial C et al and Casey BM et al. Birth weight of neonates in oligohydramnios group was less, due to chronic uteroplacental insufficiency. In present study group $60 \%$ of neonates were admitted to NICU compared to $92 \%, 16 \%$ and $7 \%$ in study by Bhagat $\mathrm{M}$ and Chawla I, Jandial $\mathrm{C}$ et al and Casey BM et al respectively. ${ }^{8}$ In a study by Melamed $\mathrm{N}$ et al, $12.8 \%$ neonates in active delivery group and $6.6 \%$ in expectant management group were admitted to NICU.

Early neonatal deaths accounted for $6 \%$ in present study group compared to $16 \%, 6 \%$ and $5 \%$ in study by Bangal $\mathrm{VB}$ et al, Jandial C et al and Casey BM et al respectively.

Thus oligohydramnios causes increased occurrence of non-reactive NST, meconium stained liquor, induction of labour, development of fetal distress, rate of LSCS, low Apgar score, low birth weight neonates, NICU admissions and early neonatal deaths.

Limitations of our study are as follows:

- Only 50 cases were included in the study.

- The diagnosis of fetal distress was made depending on the NST. However the fetal acidosis was not proved by fetal scalp blood sampling or other methods.

- Neonatal follow up after 7 days was not done.

\section{CONCLUSION}

Oligohydramnios is one of the important signs of placental insufficiency, which affects the perinatal outcome.

Oligohydramnios causes increased occurrence of nonreactive NST, meconium stained liquor, induction of labour, development of fetal distress, rate of LSCS, low Apgar score, low birth weight neonates, NICU admissions and early neonatal deaths.

Amniotic fluid index determination is a valuable parameter, which can be used as an adjunct to other fetal surveillance methods. Its help to identify those neonates at risk of poor perinatal outcome.

Identification of oligohydramnios and performing fetal surveillance tests will help us to manage the patients in a better way and will definitely improve the clinical outcome.

The determination of AFI $\leq 5 \mathrm{~cm}$ as a screening test in predicting fetal distress requiring LSCS has $81 \%$ sensitivity, $68 \%$ specificity, $60 \%$ positive predictive value and $86 \%$ negative predictive value. A better sensitivity and negative predictive value makes it a good screening test.

\section{Funding: No funding sources}

Conflict of interest: None declared

Ethical approval: The study was approved by the Institutional Ethics Committee

\section{REFERENCES}

1. Phelan JP, Smith CV, Broussard P, Small M. Amniotic fluid volume assessment with the fourquadrant technique at 36-42 weeks gestation. J Reprod Med. 1987;32(7):540-2.

2. Cunningham FG, Leveno KJ, Bloom SL, Houth JC, Rouse DJ, Spong CY. Williams Obstetrics. 23rd ed. Mc Graw Hill; 2010. pp: 45-77, 334-48.

3. Misra R. Ian Donald's Practical Obstetric Problems. 6th ed. New Dehli: BI publications pvt 1td; 2007 (reprinted 2008). pp: 369-75, 474-75.

4. Bhagat M, Chawla I. Correlation of amniotic fluid index with perinatal outcome. J Obstet Gynaecol India. 2014;64(1):32-5.

5. Jandial C, Gupta S, Sharma S, Gupta M. Perinatal Outcome after Antepartum Diagnosis of Oligohydramnios at or Beyond 34 Weeks of Gestation. JK Science: Journal of Medical Education and Research. 2007;9(4 ):213-4.

6. Melamed N, Pardo J, Milstein R, Chen R, Hod M, Yogev Y. Perinatal outcome in pregnancies complicated by isolated oligohydramnios diagnosed before 37 weeks of gestation. Am J Obstet Gynaecol. 2011;205(3):241-3.

7. Bangal VB, Giri PA, Sali BM. Incidence of oligohydramnios during pregnancy and its effects on maternal and perinatal outcome. Journal of Pharmaceutical and Biomedical Sciences (JPBMS). 2011;12(5):1-4.

8. Casey BM, McIntire DD, Bloom SL, Lucas MJ, Santos R, Twickler DM, et al. Pregnancy outcomes after antepartum diagnosis of oligohydramnios at or beyond 34 weeks gestation. Am J Obstet Gynecol. 2000;182(4):909-12.

Cite this article as: Sunita TH, Kurkure SN, Desai RM, Kamath V. A comparative analytical study of clinical outcome of oligohydramnios at or beyond 34 weeks of gestation. Int J Reprod Contracept Obstet Gynecol 2016;5:1801-8. 